A Journal of Culture, English Language, Teaching \& Literature

ISSN 1414-3320 (Print), ISSN 2502-4914 (Online)

Vol. 17 No. 1; July 2017

Copyright (c) Soegijapranata Catholic University, Indonesia

\title{
A Joint Construction Practice in Academic Writing Course in Indonesian University Context
}

\section{Aunurrahman, Fuad Abdul Hamied, and Emi Emilia}

English Education Program, Faculty of Language and Art Education, Institute of Teachers Training and Education - Teachers Association of the Republic of Indonesia Pontianak, Indonesia; English Education Program, School of Postgraduate Studies, Indonesia University of Education, Indonesia

email: yarrha@gmail.com; fuadah@indo.net.id; emi.emilia.upi@gmail.com Received: 27-04-2016 Accepted: 20-07-2017 Published: 11-08-2017 



\title{
A Joint Construction Practice in an Academic Writing Course in an Indonesian University Context
}

\author{
${ }^{1}$ Aunurrahman, ${ }^{2}$ Fuad Abdul Hamied, and ${ }^{2}$ Emi Emilia \\ 1yarrha@gmail.com; fuadah@indo.net.id; \\ 3emi.emilia.upi@gmail.com
}

${ }^{1}$ English Education Program, Faculty of Language and Art Education, Institute of Teachers Training and Education Teachers Association of the Republic of Indonesia Pontianak, Indonesia

${ }^{2}$ English Education Program, School of Postgraduate Studies, Indonesia University of Education, Indonesia

\begin{abstract}
This research aims to explore the students' writing and critical thinking capacity in a joint construction practice in an academic writing course. The course applied a genre-based approach in teaching academic writing and critical thinking to first-year English as a Foreign Language students of a private university in Pontianak, West Kalimantan, Indonesia. A combination of explicit teaching, group discussion, and online review sessions was employed in the joint construction practice for three meetings. The source for the data collection was a jointly constructed text. The text was selected from thirty-six students who worked in groups. Every group consisted of low achievers, medium achievers, and high achievers in writing. The text was analyzed using functional grammar. The analysis shows that the students had gained a good control of the exposition genre with its linguistic features. Thematic progression and logical connectors at the text level and circumstances (adverbs) at the clause level had realized critical thinking skills and dispositions. Several grammatical mistakes and improper lexical choices were identified but did not interfere with the purpose of the text. The findings suggest that having more classroom meetings will make explicit teaching and group discussion work effectively before the students begin to write independently. Moreover, online review sessions can support the students' learning but with limitations.
\end{abstract}


28 Celt: A Journal of Culture, English Language Teaching and Literature, Volume 17, Number 1, July 2017, pp. 27 - 44

Key words: a genre-based approach, joint construction practice, academic writing, critical thinking

Abstrak: Penelitian ini bertujuan untuk mengeksplorasi kapasitas menulis mahasiswa pada tahap latihan konstruksi bersama dalam menulis teks akademik. Pendekatan berbasis genre diterapkan dalam pengajaran menulis teks akademik dan berpikir kritis kepada mahasiswa tahun pertama Program Studi Pendidikan Bahasa Inggris dari suatu perguruan tinggi swasta di Pontianak, Kalimantan Barat, Indonesia. Kombinasi pengajaran eksplisit, diskusi kelompok, dan sesi reviu daring digunakan dalam latihan konstruksi bersama selama tiga pertemuan. Sumber data penelitian ini adalah teks dari latihan tersebut. Teks tersebut diseleksi dari tiga puluh enam mahasiswa yang bekerja dalam kelompok. Setiap kelompok terdiri dari mahasiswa dengan kategori berprestasi rendah, sedang, dan tinggi dalam menulis. Teks kemudian dianalisis menggunakan tata bahasa fungsional. Analisis teks menunjukkan mahasiswa memiliki kendali yang baik atas genre eksposisi dengan fitur linguistiknya. Progresi tematik dan konektor logis di tingkat teks dan penggunaan fitur sirkumstansial di tingkat klausa merealisasi kemampuan dan disposisi berpikir kritis mahasiswa. Beberapa kesalahan tata bahasa dan ketidaktepatan pilihan kata diidentifikasi namun tidak berpengaruh pada tujuan teks yang dianalisis. Temuan ini menyarankan untuk menambah pertemuan di kelas agar pengajaran eksplisit dan diskusi kelompok dapat bekerja lebih efektif sebelum mahasiswa mulai menulis secara independen. Kemudian, sesi reviu daring mendukung pembelajaran mahasiswa namun terbatas.

Kata kunci: pendekatan berbasis genre, latihan konstruksi bersama, menulis ilmiah, berpikir kritis

\section{INTRODUCTION}

University students around the world are required to learn academic writing. It involves a particular set of knowledge and skills that are necessary for the students to master. Apart from the particular set of knowledge and skills, an important feature that is also considered in this research is critical thinking (Emilia, 2005; Widodo, 2012). Critical thinking is more than just skills. It also has dispositions that act as guidance in constructing an academic text (Ennis, 1996; Siegel, 2010). 
Aunurrahman, Hamied, F. A., \& Emilia, E., A Joint Construction Practice 29 in an Academic Writing Course in an Indonesian University Context

First-year university students should already have the knowledge and skills in academic writing and critical thinking as many academic assignments are assigned to them, starting with essays, then, term papers or research papers. In order to achieve this particular set of knowledge and skills, an academic writing course should be equipped with a practical approach.

An approach that deals with different text types is a genre-based approach under systemic functional linguistics (Derewianka, 1990, 2012; Emilia, 2012). The genre-based approach has been developed in Australia (Hyland, 2007; Swales, 2012) and has been applied around the world including in Indonesia (Derewianka, 2003; Emilia, 2005).

In Indonesia, the genre-based approach used commonly has four teaching stages (Emilia, 2012), which is also has been used in a university context (Aunurrahman, Hamied, \& Emilia, 2016, 2017). The stages are building knowledge of the field, modeling, joint construction, and independent construction stages (Emilia, 2012). From the four stages, this research aims to explore the students' capacity in academic writing and critical thinking in the joint construction stage of an academic writing course in an Indonesian university context. The research involved first-year EFL students of a private university in Pontianak, West Kalimantan, Indonesia.

\section{THE CONCEPT OF ACADEMIC WRITING}

This section will discuss the concept of academic writing that consists of a particular set of knowledge and skills. The discussion of the concept of academic writing will be related to the concept of critical thinking (hereafter CT) as both concepts share a common ground.

Academic writing consists of a particular set of knowledge and skills. In brief, knowledge is about what to write. It deals with selecting and limiting a topic that the students want to write about. In order to select a topic, the students should grasp ideas and arguments from any relevant references. After searching for ideas and arguments, the students should limit the ideas and arguments that will be used in his or her writing (Irvin, 2010).

Certainly, using relevant reference and selected ideas and arguments involve the application of dispositions of CT that guide the students not only in performing CT but also in constructing an academic text. The relevant references are part of relevance, a disposition of CT, where ideas should be grasped from references that are relevant to the topic that will be written 
(Elder \& Paul, 2010, 2013). Then, selected ideas and arguments that the students want to use in their writing involve dispositions of CT in terms of clarity, accuracy, and precision where in constructing a text, the students should use clear, accurate, and precise information and evidence (Elder \& Paul, 2010, 2013). In this study, dispositions used are also called as intellectual standards. Other dispositions or intellectual standards are depth, breadth, logicalness, and fairness (Elder \& Paul, 2010, 2013). This research also considers respect as a disposition of CT (Bailin \& Siegel, 2003; Siegel, 2010), which mainly involved in the practice of the ethics of academic writing. The ethics of academic writing fall under the term of how to write that will be elaborated in the following paragraphs.

After considering about what to write, the students should also master the skills of academic writing. In this research, the skills are about how to write (Irvin, 2010) that involves a genre with its linguistic features (Bruce, 2008a, 2013), which is also known as discourse competence (Bruce, 2008b). In university contexts, argumentative writing is considered important (Coffin \& Donohue, 2012; Emilia, 2010; Promwinai, 2010; Wingate, 2012) as it can develop the students' critical thinking (DasBender, 2011; Nesi \& Gardner, 2006).

Argumentative writing under the systemic functional linguistics genrebased approach (hereafter SFL GBA) consists of two genres. The genres are an exposition genre and a discussion genre. Both genres have 'persuading that' and 'persuading to' functions (see Coffin, 2004; Schulze, 2011). This research, however, will only explore the exposition genre.

An exposition genre, like any genre under systemic functional linguistics (hereafter SFL), has a social function, structure or stages, and its linguistic features (Martin, 1992, 2010). The social function of an exposition genre is "to present arguments in favour of a position that needs to be argued for" (Halliday \& Martin, 1993, p. 216). Then, the schematic structure of an exposition genre consists of three elements. The elements are a thesis - a main topic that will be argued; arguments - supporting details of the main topic; and reiteration of thesis - a summary of the topic conveying the arguments and a recommendation if necessary (Martin, 2006). The structure of an exposition genre can be a realization of information-organizing skills of CT (Lipman, 2003).

The latter element that plays an important part in writing an exposition genre is linguistic features. To mention a few, the linguistic features of an exposition genre are: (1) generalized participants that deal with 
Aunurrahman, Hamied, F. A., \& Emilia, E., A Joint Construction Practice 31 in an Academic Writing Course in an Indonesian University Context

abstract issues, (2) timeless present tense when communicating a position or a point of an argument; (3) passive voice; (4) nominalization to make an argument sounds more objective; (5) logical connectors to create a logical order of a writing; and (6) a hedged language such as modalities, mental processes, and circumstances, which is a form of a cautious language in communicating a position or a claim (Derewianka, 1990, pp. 76-78; Gillett, 2017).

Another main focus of this research is the ethics of academic writing, which has been mentioned earlier under the term what to write. The ethics of academic writing is about how to provide factual evidence or supporting details that are relevant to the arguments and the topic of the students' writing in an ethical way that realizes respect as a disposition of CT. The practice of the ethics of academic writing also can realize the students' academic honesty where the students learn to use someone's ideas in their writing that can build credibility of their writing (Jones, 2011). The ethics of academic writing cover quoting exact words from other texts, paraphrasing and summarizing ideas of other texts or references by using one's own words, and writing a reference list under APA style, which is commonly used in academic writing (Bailey, 2006; Oshima \& Hogue, 1999; Paiz et al., 2014).

Up to this point, the concept of academic writing of this study consists of a particular set of knowledge and skills that share a common ground with the concept of CT. The concept would be learned by the students through the application of a genre-based approach under SFL GBA that consists of four stages. This research, however, will only explore the students' capacity in academic writing and CT in a joint construction stage of an academic writing course.

\section{METHODOLOGY}

This research aims to explore the students' capacity in academic writing and CT in a joint construction stage in an academic writing course. It involved the first-year EFL students of a private university in Pontianak, West Kalimantan, Indonesia. The students agreed to participate in this research as they had signed a consent form. The academic writing course used four stages of a genre-based approach that has been applied in Indonesia (Emilia, 2012) with the implementation of a combination of explicit teaching, group discussion, and online review sessions. 
A diagnostic test was conducted in the first session to see the students' prior performance in academic writing and CT. After the diagnostic test, the students had introductory sessions to CT and SFL GBA as an overview of the concept of CT and academic writing under SFL GBA that has been elaborated in the literature review above. The teaching practice began with building knowledge of the field where the students built their knowledge of a topic (Feez, 2002). The second stage was modeling stage. The researcher acted as a lecturer provided model texts of an exposition genre. Then, the students learned to identify the schematic structure and linguistic features of an exposition text, intellectual standards or dispositions of CT, and in-text citations as part of the ethics of academic writing (adapted from Feez, 2002).

The third stage was a joint construction stage. The students constructed their texts for the first time in groups (Feez, 2002). Each group consisted of low achievers, medium achievers, and high achievers. The categories assigned to the students were based on a diagnostic test conducted before the course. To assist the students, the lecturer guided the students to organize their arguments that had been built in the previous stage. The lecturer also guided the students to practice the ethics of academic writing that included quoting, paraphrasing, summarizing, and writing a reference list under APA style.

The joint construction took three meetings. However, the lecturer realized that the students still had many things to learn before they constructed their own text. Accordingly, the lecturer conducted two online review sessions. The students submitted their texts via e-mail to the lecturer to be given feedback. The online review sessions were necessary to prepare them for more practices that were limited in the independent construction stage as they began to work independently with limited explicit teaching from the lecturer and peer feedback was much encouraged.

In order to achieve the aim of this research, a document or a text was selected from a group of students in the joint construction stage. The group consisted of three students with different levels of writing performance. They were Sari - a low achiever; Erick - a medium achiever; and Rendi - a high achiever (their names are in pseudonym). The functional grammar was used in the text analysis that covered the textual metafunction, ideational metafunction, and interpersonal metafunction of the students' text (Fontaine, 2013; Halliday \& Matthiessen, 2014). The analysis also included the application of intellectual standards or dispositions of CT and in-text citations. The following section will report the results of the text analysis. 
Aunurrahman, Hamied, F. A., \& Emilia, E., A Joint Construction Practice 33 in an Academic Writing Course in an Indonesian University Context

\section{FINDINGS AND DISCUSSION}

This section will describe the text analyzed using functional grammar. Before that, this paper will show an example of the lecturer's feedback in the online review sessions. The online review sessions employed by the researcher as the lecturer provided feedback on the students' texts, as the three meetings were not sufficient to cover academic writing along with its ethics and CT. The text selected for the example was jointly constructed by Sari - a low achiever; Erick - a medium achiever; and Rendi - a high achiever (their names are in pseudonym). In order to save space, the example is taken from the first online review session, which was communicated by e-mail. The example of the lecturer's feedback is in Table 1 .

\section{Table 1:}

\section{Lecturer's Feedback on the Jointly-constructed Text}

Line First draft of the jointly constructed text
A good teacher is not difficult to find. However, it does not mean
everyone can be a teacher and not all teachers is are good teachers. At this
point, it is better to say that a good teacher should have at least three
important criteria.
First, a good teacher inspires his/her students. An inspiring teacher
means that a teacher is not only teaching, but also motivates his/her
students to be better. A good teacher also means that a teacher who can
make a difference in the lives of his/her students by making the students to
see things differently (Gonchar, 2015).
Second, a good teacher is an entertainer in the positive sense not the
negative sense. It means that a good teacher is not only giving his/her
students knowledge seriously during the class but also make them
comfortable in the class, although in the serious learning situation
(Harmer, 2001).
Third, a good teacher has good classroom management skills. It
means that a teacher should keep the balance of his/her students'
performance in the class (Harmer, 2001 ). For example, a quite student
should be given the opportunity to answer the question and speak up in
the class as the attractive one does.
In conclusion, a good teacher should be able to inspire his/her
students, alse an entertainer elassroom in the a positive sense, and must
have an effective classroom management skills. However, a good teacher
should not be limited by these criteria. A teacher must find more criteria to


become not only a good teacher but also a better teacher to make a better student.

\section{REFERENCES}

Gonchar, M. (2013, April 1). When Has a Teacher Inspired You? The Learning Network. Retrieved from http://learning.blogs.nytimes.com/2013/01/04/when-has-a-teacherinspired-you/

Harmer, Jeremy. (2001). How to Teach English (1 ${ }^{\text {st }}$ Ed). New York: CNNLongman.

\section{Notes:}

- Bold words or expressions show suggestion from the lecturer

- Strikethrough words or expressions show words or expressions that are considered to be omitted in the text

Table 1 shows that the lecturer informed explicitly any missing information or parts as indicated in line 4 where the lecturer suggested a thesis statement. Suggestions for proper grammar, spelling, lexical choices, and a reference list under APA style as part of dispositions of CT and ethics of academic writing were also communicated in the text. The function of explicit teaching is to provide clear guidance to the students. It should also enable the students to focus on any parts of the text that have not been well developed (Feez, 2002; Hyland, 2007; Martin \& Rose, 2008). Still, there are limitations. First, the lecturer did not show every mistake in the text as the lecturer expected the students to find out on his or her own. However, it did not happen. Later, in the text analysis, the text still has a few mistakes that the students were not aware of. It seemed that the students took the lecturer's feedback for granted without developing it any further. Second, the lecturer was unable to monitor every group work until they submitted their texts. After the second online review session, the students submitted their final texts by e-mail. A jointly constructed text was selected from a group of students for the text analysis. The students were Sari - a low achiever; Erick a medium achiever; and Rendi - a high achiever (their names are in pseudonym). The text is in Table 2. In the analysis, the text consists of three elements of an exposition text with each clause numbered.

Table 2:

Final Draft of the Jointly Constructed Text

A GOOD TEACHER 
Aunurrahman, Hamied, F. A., \& Emilia, E., A Joint Construction Practice 35 in an Academic Writing Course in an Indonesian University Context

Thesis element

1. A good teacher is not difficult to find.

2. However, it does not mean everyone can be a teacher a

3. and not all teachers are good teachers.

4. It can be said that a good teacher should have at least three important criteria.

Argument element

5. First, a good teacher inspires his/her students.

6. An inspiring teacher means that a teacher is not only teaching

7. but also motivates (motivating) his/her students to be better.

8. A good teacher also means that a teacher who can make a difference in the lives of his/her students by making the students to see things differently (Gonchar, 2015).

9. Second, a good teacher is an entertainer in the positive sense not the negative sense.

10. It means that a good teacher is not only giving his/her students knowledge seriously during the class

11. but also make (making) them comfortable in the class including in a serious learning situation (Harmer, 2001).

12. Third, a good teacher has good classroom management skills.

13. It means that a teacher should keep a balance of his/her students' performance in the class (Harmer, 2001).

14. For example, a quite (quiet) student should be given the opportunity to answer a question and speak up in the class.

Reiteration of thesis element

15. In conclusion, a good teacher should be able to provide inspirations, entertainment in a positive sense, and must have effective classroom management skills.

16. However, a good teacher should not be limited by these criteria.

17. Instead, a teacher must find more criteria to become not only a good teacher but also a better teacher for his/her students.

References

Gonchar, M. (2013, April 1). When Has a Teacher Inspired You? The Learning Network. Retrieved from

http://learning.blogs.nytimes.com/2013/01/04/when-has-a-teacherinspired-you/

Harmer, Jeremy. (2001). How to Teach English (1 ${ }^{\text {st }}$ Ed). New York: Longman.

Note:

- Bold words or expressions show grammatical mistakes and improper lexical choices followed by suggestions in parentheses.

Table 2 shows that the final draft of the jointly constructed text is 
currently much better than the first draft (see Table 1). Still, several grammatical mistakes were identified in the text but did not interfere with the purpose of the text. A further text analysis will cover textual metafunction, ideational metafunction, interpersonal metafunction, and identifications of dispositions of CT and ethics of academic writing.

Textual metafunction describes the organization of the text realized by Theme system. This also involves logical metafunction realized by conjunctions, which is a part of ideational metafunction, that describes how language provides a connection in a sentence to a text (Halliday \& Matthiessen, 2014). The description will begin with Thematic progression. The text used derived Themes that commonly utilized in an exposition text (Emilia, 2014). The Thematic progression of the text is presented in Table 3.

Table 3:

The Thematic Progression of the Jointly Constructed Text

\begin{abstract}
macroTheme:
It can be said that a good teacher should have at least three important criteria.

hyperThemes:

First, a good teacher inspires his/her students.

Second, a good teacher is an entertainer in the positive sense not the negative sense.

Third, a good teacher has good classroom management skills.

macroNew:
\end{abstract}

$\underline{\text { In conclusion, }}$ a good teacher should be able to provide inspirations, entertainment in a positive sense, and must have effective classroom management skills.

\title{
Note:
}

- The underlined expressions are logical conjunctions which introduce the hyperThemes or arguments

Table 3 shows that the macroTheme or main idea of the text is three criteria of a good teacher. In relation to dispositions of CT, the main idea reflects clear, accurate, and precise information where the students limited the arguments into three arguments. The hyperThemes are considered as arguments as logical connectors precede the hyperThemes: First, Second, and Third realize textual Theme and logical metafunction. The hyperThemes, in relation to intellectual standard or disposition of CT, reflect relevant 
Aunurrahman, Hamied, F. A., \& Emilia, E., A Joint Construction Practice 37 in an Academic Writing Course in an Indonesian University Context

arguments as the hyperThemes used topical Themes that are pertinent to the macroNew, which is, a good teacher. The latter part is macroNew. This is a summary of the text signaled by a logical connector with a summative function: In conclusion. The macroNew is also relevant to the thesis and argument elements as it uses a relevant topical Theme as well.

At the clause level, the argument element will be presented to see arguments with their elaborations. An example of the argument with its elaboration is presented in Table 4.

Table 4:

An Example of an Argument from the Jointly Constructed Text

1. First, a good teacher inspires his/her students.
2. An inspiring teacher means that a teacher is not only teaching
3.
but also motivates (motivating) his/her students to be better.
A good teacher also means that a teacher who can make a difference in
the lives of his/her students by making the students to see things
differently (Gonchar, 2015).

Note:

- Bold words or expressions show grammatical mistakes and improper lexical choices followed by the suggestion in parentheses.

Table 4 presents an argument that a good teacher inspires his/her students. There is no textual Theme or logical connector that signals an elaboration (see Clause No. 2). Instead, a topical Theme is used as a point of elaboration: An inspiring teacher. The topical Theme itself derived from the Rheme in the earlier clause: inspires his/her students. This, concerning dispositions of CT, reflects relevance between the argument with its elaborations. At the end of the elaboration, there is a citation that indicates the elaboration is based on a reference, which makes the argument credible. Another function of the citation is to signal a realization of the ethics of academic writing and a form of respect under CT dispositions. The citation is followed by a reference list (see Table 2) in APA style (2010) that had been introduced by the lecturer. Having a reference list strengthens the credibility of the argument as long as the reference is a valid one (Jones, 2011).

Concerning ideational metafunction, as logical metafunction has been delineated along with textual metafunction, only experiential metafunction will be presented. Experiential metafunction describes a process or experience along with its participants and circumstances that occur in the text and realized by Transitivity system (Halliday \& Matthiessen, 2014). The 
text uses several types of processes along with their participants and circumstances effectively. For example, in Table 4, a clause (No. 4) realizes an identifying relational process followed by a causal relational process: A good teacher [Token] also means [Pr: Identifying] that a teacher [[who [Token] can make [Pr: Causal] a difference [Value] in the lives of his/her students [Circumstance: Location: Place] by making the students to see things differently [Circumstance: Manner: Means]] [Value]. The participants in the text are mainly a good teacher with different roles as the main idea of the text is a good teacher. The circumstances also have several functions. In the passage provided, two circumstances have location and manner functions. These circumstances reflect dispositions of CT in terms of clarity, accuracy, and precision of information in a clause.

The next metafunction is interpersonal metafunction. It describes the language used in interaction with the reader realized by mood system (Thompson, 2014). The text mainly uses declarative mood in elaborating arguments of the issue under discussion (see Emilia \& Hamied, 2015). Then, the text employed epistemic modality and deontic modality. An epistemic modality signals a probability (Halliday \& Matthiessen, 2014). For example, it is realized by can in A good teacher also means that a teacher who can make a difference in the lives of his/her students by making the students to see things differently (Gonchar, 2015). The level of can is medium and as the clause supplies a citation, it creates a stronger possibility of the meaning of the clause. Then, a deontic modality functions as an obligation (Halliday \& Matthiessen, 2014) is realized by, for example, should in It means that a teacher should keep a balance of his/her students' performance in the class (Harmer, 2001). Should signals a suggestion with a medium level of modality with a paraphrase projected in the clause to strengthen the suggestion. Another feature identified in the text is an impersonal passive voice in the thesis element: It is said (see clause No. 4 in Table 2). Impersonal passive voice, which is a form of academic language, helps the text to focus on the issue as it removes agency and it signals an objective statement (Pullum, 2014; Schleppegrell, 2009).

Up to this point, the jointly constructed text shows the students had gained a good control of the schematic structure of an exposition text with various linguistic features. Dispositions of CT such as clarity, accuracy, precision, and relevance were identified in the text. Respect was also identified in the text in the form of in-text citations with a reference list under APA style. Grammatical mistakes and improper lexical choices were identified but they did not interfere with the purpose of the text. This finding is in line with several previous research on a genre-based approach in 
Aunurrahman, Hamied, F. A., \& Emilia, E., A Joint Construction Practice 39 in an Academic Writing Course in an Indonesian University Context

teaching academic writing and CT to tertiary EFL students in Indonesia (Emilia, 2005; Emilia \& Hamied, 2015). Moreover, the finding also shows that explicit teaching and group discussion were not in maximum performance. Limitations of the online review sessions should be addressed to improve explicit teaching and group discussion practices ensuring a better preparation before the students construct their writing independently.

\section{CONCLUSION}

This research aims to explore a joint construction stage of an academic writing course that involved EFL students of a private university in Pontianak, West Kalimantan, Indonesia. The research confirms the previous research that a genre-based approach can develop tertiary EFL students' academic writing and CT in Indonesia. Still, the text analysis found a limitation, that is, several grammatical mistakes and limited lexical choices were identified in the jointly constructed text, but they did not interfere with the purpose of the text.

Online review sessions can support the students' learning. However, it cannot replace classroom meetings. Having more classroom meeting for the joint construction practice is necessary especially when the academic course is for the first-year EFL students. Certainly, explicit teaching and group discussion should be improved by addressing the students' difficulties in academic writing and CT. It will provide a better preparation for the students before they work independently. Future research should seek another combination of teaching strategies for a joint construction practice of an academic writing course.

\section{REFERENCES}

American Psychological Association (Ed.). (2010). Publication manual of the American Psychological Association (6th ed.). Washington, DC: American Psychological Association.

Aunurrahman, Hamied, F. A., \& Emilia, E. (2016). Facilitating character building through an academic writing practice. Arab World English Journal, 7(3), 146-160. https://doi.org/dx.doi.org/10.24093/ awej/vol7no3.11 
40 Celt: A Journal of Culture, English Language Teaching and Literature, Volume 17, Number 1, July 2017, pp. 27 - 44

Aunurrahman, Hamied, F. A., \& Emilia, E. (2017). Exploring the tertiary EFL students' academic writing competencies. Indonesian Journal of Applied Linguistics, 7(1), 72-79. https://doi.org/dx.doi.org/10.17509/ ijal.v7i1.6860

Bailey, S. (2006). Academic writing: A handbook for international students (2nd ed.). New York: Taylor \& Francis e-Library.

Bailin, S., \& Siegel, H. (2003). Critical thinking. In N. Blake, P. Smeyers, R. D. Smith, \& P. Standish (Eds.), The Blackwell guide to the philosophy of education (pp. 181-193). Oxford, UK: John Wiley \& Sons.

Bruce, I. (2008a). Academic writing and genre: A systematic analysis. New York, NY: Continuum.

Bruce, I. (2008b). Theorising tertiary writing instruction: Accounting for the process, post-process, genre and critical literacies approaches. In Proceedings of the TWN Biennial Colloquium: From here to there, December 2-3, AUT University, Auckland, New Zealand. Retrieved from http://researchcommons.waikato.ac.nz/handle/10289/2053

Bruce, I. (2013). A role for genre-based pedagogy in academic writing instruction: An EAP perspective. TEXT Journal, (21), 1-15.

Coffin, C. (2004). Arguing about how the world is or how the world should be: The role of argument in IELTS tests. Journal of English for Academic Purposes, 3(3), 229-246. https://doi.org/10.1016/j.jeap.2003.11.002

Coffin, C., \& Donohue, J. P. (2012). Academic literacies and systemic functional linguistics: How do they relate? Journal of English for Academic Purposes, 11(1), 64-75. https://doi.org/10.1016/j.jeap.2011.11.004

DasBender, G. (2011). Writing spaces: Readings on writing (Vol. 2). Anderson, SC: Parlor Press. Retrieved from http://wac.colostate.edu/books/ writingspaces $2 /$

Derewianka, B. (1990). Exploring how texts work. Rozelle, NSW: Primary English Teaching Association.

Derewianka, B. (2003). Trends and issues in genre-based approaches. RELC Journal, 34(2), 133-154. https://doi.org/10.1177/0033688203 03400202 
Aunurrahman, Hamied, F. A., \& Emilia, E., A Joint Construction Practice 41 in an Academic Writing Course in an Indonesian University Context

Derewianka, B. (2012). Knowledge about language in the Australian curriculum: English. Australian Journal of Language and Literacy, 35(2), $127-146$.

Elder, L., \& Paul, R. (2010, October). Universal intellectual standards. Retrieved December 6, 2014, from http://www.criticalthinking.org/ pages/universal-intellectual-standards/527

Elder, L., \& Paul, R. (2013). Critical thinking: Intellectual standards essential to reasoning well within every domain of human thought. Journal of Developmental Education, 36(3), 34-35.

Emilia, E. (2005). A critical genre-based approach to teaching academic writing in a tertiary EFL context in Indonesia (Unpublished Dissertation). The University of Melbourne, Melbourne. Retrieved from https://minervaaccess.unimelb.edu.au/handle/11343/39548

Emilia, E. (2010). Teaching writing: Developing critical learners. Bandung, Indonesia: Rizqi Press.

Emilia, E. (2012). Pendekatan genre-based dalam pengajaran bahasa Inggris: Petunjuk untuk guru (2nd ed.). Bandung, Indonesia: Rizqi Press.

Emilia, E. (2014). Introducing functional grammar. Bandung, Indonesia: Pustaka Jaya.

Emilia, E., \& Hamied, F. A. (2015). Systemic functional linguistic genre pedagogy (SFL GP) in a tertiary EFL writing context in Indonesia. TEFLIN Journal, 26(2), 155. https://doi.org/10.15639/teflin journal.v26i2/155-182

Ennis, R. H. (1996). Critical thinking dispositions: Their nature and assessability. Informal Logic, $18(2 \& 3), 165-182$.

Feez, S. (2002). Heritage and innovation in second language education. In A. M. Johns (Ed.), Genre in the classroom: Multiple perspectives (pp. 47-68). Mahwah, NJ: Lawrence Erlbaum.

Fontaine, L. (2013). Analysing English grammar: A systemic-functional introduction. Cambridge: Cambridge University Press. 
42 Celt: A Journal of Culture, English Language Teaching and Literature, Volume 17, Number 1, July 2017, pp. 27 - 44

Gillett, A. (2017, March 17). Features of academic writing. Retrieved April 7, 2017, from http://www.uefap.com/writing/feature/featfram.htm

Halliday, M. A. K., \& Martin, J. R. (1993). Writing science literacy and discursive power. London: Falmer Press. Retrieved from http://search.ebscohost. com/login.aspx?direct $=$ true $\&$ scope $=$ site $\& d b=$ nlebk $\& d b=$ nlabk $\& A N=9$ 8404

Halliday, M. A. K., \& Matthiessen, C. M. I. M. (2014). Halliday's introduction to functional grammar (4th ed.). Oxfordshire, UK: Routledge.

Hyland, K. (2007). Genre pedagogy: Language, literacy and L2 writing instruction. Journal of Second Language Writing, 16(3), 148-164. https://doi.org/10.1016/j.jslw.2007.07.005

Irvin, L. L. (2010). What is "Academic" writing? In Writing spaces: Readings on writing (Vol. 1, pp. 3-17). West Lafayette, IN: Parlor Press.

Jones, L. R. (2011). Academic integrity $\mathcal{E}$ academic dishonesty: A handbook about cheating $\mathcal{E}$ plagiarism (Revised \& Expanded Edition). Melbourne, Florida: Florida Institute of Technology. Retrieved from https://www.fit.edu/current/documents/plagiarism.pdf

Lipman, M. (2003). Thinking in education (2nd ed.). New York, US: Cambridge University Press. Retrieved from http://dx.doi.org/10.1017 /CBO9780511840272

Martin, J. R. (1992). English text: System and structure. Philadelphia: John Benjamins Pub. Co.

Martin, J. R. (2006). Mentoring semogenesis: "genre-based" literacy pedagogy. In F. Christie (Ed.), Pedagogy and the Shaping of Consciousness: Linguistic and Social Processes (pp. 123-155). London, UK: Continuum.

Martin, J. R. (2010). Semantic variation - modelling realisation, instantiation and individuation in social semiosis. In J. R. Martin \& M. Bednarek (Eds.), New Discourse on Language Functional Perspectives on Multimodality, Identity, and Affiliation (pp. 1-34). New York, NY: Continuum.

Martin, J. R., \& Rose, D. (2008). Genre relations: Mapping culture. London, UK: Equinox Publishing.

Nesi, H., \& Gardner, S. (2006). Variation in disciplinary culture: University 
Aunurrahman, Hamied, F. A., \& Emilia, E., A Joint Construction Practice 43 in an Academic Writing Course in an Indonesian University Context

tutors' views on assessed writing tasks. In R. Kiely, P. Rea-Dickins, \& H. Woodfield (Eds.), Language, Culture and Identity in Applied Linguistics: Selected Papers from the Annual Meeting of the British Association for Applied Linguistics, University of Bristol, September 2005 (pp. 99-117). London, UK: British Association for Applied Linguistics in association with Equinox.

Oshima, A., \& Hogue, A. (1999). Writing academic English (3rd ed.). New York: Addison Wesley Longman.

Paiz, J. M., Angeli, E., Wagner, J., Lawrick, E., Moore, K., Anderson, M., ... Keck, R. (2014, November 11). Purdue OWL: APA Formatting and Style Guide. Retrieved January 19, 2017, from https://owl.english.purdue.edu/owl/owlprint/560/

Promwinai, P. (2010). The demands of argumentative essay writing: Experiences of Thai tertiary students (Doctor of Education thesis). Faculty of Education, University of Wollongong, New South Wales. Retrieved from http://ro.uow.edu.au/cgi/viewcontent.cgi?article $=4298 \&$ context=these $\mathrm{s}$

Pullum, G. K. (2014). Fear and loathing of the English passive. Language $\mathcal{E}^{2}$ Communication, 37, 60-74. https://doi.org/10.1016/j.langcom. 2013.08.009

Schleppegrell, M. J. (2009). Language in academic subject areas and classroom instruction: What is academic language and how can we teach it? Presented at the Workshop on the Role of Language in School Learning: Implications for Closing the Achievement Gap, October 1516, Hewlett Foundation, Menlo Park, CA. Retrieved from https://www.mydigitalchalkboard.org/cognoti/content/file/resources/ documents/98/98c3e7f4/98c3e7f49b44eaa5ee60b45939df619b4593af c7/Schleppegrell.pdf

Schulze, J. (2011). Writing to persuade: A systemic functional view. GIST Education and Learning Research Journal, (5), 127-157.

Siegel, H. (2010). Critical thinking. International Encyclopedia of Education, 6, 141-145. https://doi.org/10.1016/B978-0-08-044894-7.00582-0

Swales, J. M. (2012). A text and its commentaries: Toward a reception history of "Genre in three traditions"(Hyon, 1996). Ibérica: Revista de La 
44 Celt: A Journal of Culture, English Language Teaching and Literature, Volume 17, Number 1, July 2017, pp. 27 - 44

Asociación Europea de Lenguas Para Fines Especificos (AELFE), (24), 103115.

Thompson, G. (2014). Introducing functional grammar (3rd ed.). New York: Routledge.

Widodo, H. P. (2012, February 26). Five key issues in academic writing: Writing scholarly articles in English. GoLive Indonesia. Retrieved from http://goliveindonesia.com/2012/02/27/five-key-issues-in-academicwriting-writing-scholarly-articles-in-english/

Wingate, U. (2012). "Argument!" helping students understand what essay writing is about. Journal of English for Academic Purposes, 11(2), 145-154. https://doi.org/10.1016/j.jeap.2011.11.001

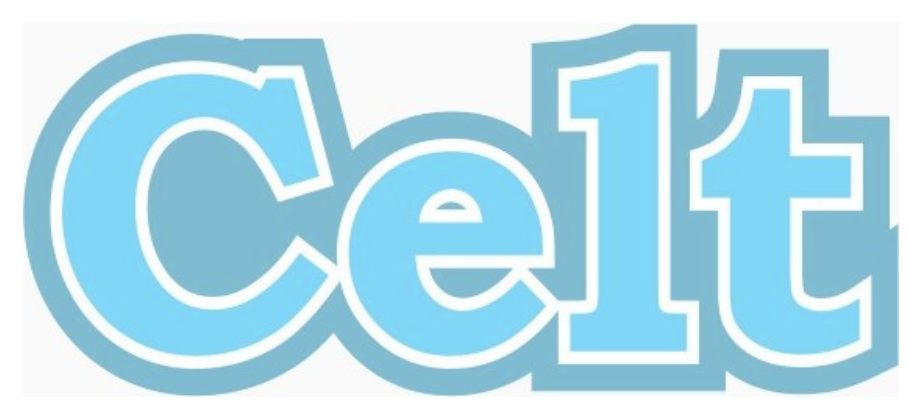

